Allowance. Per. from English -2 ed]. M .: UNITY-DANA

13. Dykan V. Upravlinnja jakistju jak faktor konkurentospromozhnosti pidpryjemstv [Quality management as a factor of competitiveness of enterprises] / В. Дикань // Економіка України. -1996. -№1-С.43-48.

14. Dykan V.L., Lysjonkova N.M. (2005) Suchasni systemy upravlinnja jakistju produkciji [Modern quality management systems]. The bulletin of Transport and Industry Economics. No. 12, pp. 229 - 235.

15. Kalyta P. (2010) Systema upravlinnja jakistju: «za standartom» chy za specyfikoju pidpryjemstva? [Quality management system: "according to the standard" or the specifics of the enterprise?]. The world of quality of Ukraine. No. 3, pp. 102-104.

16. Kudla N.Je. (2015) Upravlinnja jakistju $v$ turyzmi: pidruchnyk [Quality management in tourism: a textbook]. $\mathrm{K}$.: "Center for Educational Literature". (in Ukrainian)

17. Munin Gh.B.

(2007) Orghanizacija obslughovuvannja u malykh ghoteljakh: navchaljnyj posibnyk [Organization of service in small hotels: a manual]. $\mathrm{K}$ : Publishing House of the European University. (in Ukrainian)
18. Pisarevsky I.M., Poghassi S.O., Pocolodn M. M. etc. (2008) Orghanizacija turyzmu: pidruchnyk [Tourism organization: a textbook]. X .: KNOW (in Ukrainian)

19. Sokol T.G. (2009) Orghanizacija obslughovuvannja $v$ ghoteljakh $i$ turystychnykh kompleksakh [Organization of service in hotels and tourist complexes]. K .: Altepres. (in Ukrainian)

20. Shapoval

M.I. (2007) Menedzhment jakosti: pidruchnyk [Quality Management: Tutorial]. K.: Knowledge. (in Ukrainian)

21. Kyrychenko O.A., Zakharov O.I., Denysenko M.P. ta in. (2010) Ekonomichna bezpeka sub'jektiv ghospodarsjkoji dijaljnosti v umovakh ghlobaljnoji finansovoji kryzy: monoghrafija [Economic security of economic entities in the context of the global financial crisis: a monograph]. K.: Dorado-Print Ltd. (in Ukrainian)

22. Cherednychenko A.O., Kalynyn M.V. (2016) Jakistj nadannja poslugh jak kljuchovyj faktor pryvablyvosti pidpryjemstv ghoteljnogho ghospodarstva [The quality of service provision as a key factor in the attractiveness of the hotel industry]. The bulletin of Transport and Industry Economics. No. 56, pp. 88-96.

\title{
НЕОБХІДНІСТЬ ФОРМУВАННЯ ПОЗИТИВНОГО ІМІДЖУ ПІДПРИЕМСТВА ЯК ІНСТРУМЕНТУ ВНУТРІШНЬОГО СТРАТЕГІЧНОГО УПРАВЛІННЯ
}

\author{
Чупир О.М., д.е.н., доцент, професор (ХНУБА)
}

\begin{abstract}
У статті розглянуто значення та сутність використання позитивного іміджу для підприємства, обгрунтовано доцільність його створення. Акцентовано увагу на узагальненні факторів, які впливають на створення позитивного іміджу підприємства, на виконанні певних задач щодо його досягнення. Розроблено модель формування позитивного іміджу підприємства в умовах сучасного економічного становища, щуо дасть можливість не тільки підвищити ефективність роботи
\end{abstract}


підприємства в изілому, а й зміцнити його конкурентні позищії, в результаті чого иче призведе щэодо досягнення економічного та сочіального ефекту.

Ключові слова: імідж, позитивний імідж, модель, формування позитивного іміджу, стратегічне управління, іміджеві еквіваленти.

\title{
НЕОБХОДИМОСТЬ ФОРМИРОВАНИЯ ПОЛОЖИТЕЛЬНОГО ИМИДЖА ПРЕДПРИЯТИЯ КАК ИНСТРУМЕНТА ВНУТРЕННЕГО СТРАТЕГИЧЕСКОГО УПРАВЛЕНИЯ
}

\author{
Чупырь Е.Н., д.э.н., доцент, профессор (ХНУСА)
}

\begin{abstract}
В статье рассмотрены значение и сущуность использования положительного имиджа предприятия, обоснована иелесообразность его создания. Акиентировано внимание на обобщении факторов, влияющих на создание положительного имиджа предприятия, на выполнении определенных задач относительно его достижения. Разработана модель формирования положительного имиджа предприятия в условиях современного экономического положения, что даст возможность не только повысить эффрективность работь предприятия в изелом, но и укрепить его конкурентные позиции, в результате чего это приведет $\kappa$ достижению экономического $u$ соииального эффекта.
\end{abstract}

Ключевые слова: имидж, положительный имидж, модель, формирование положительного имиджа, стратегическое управление, имиджевые эквиваленты.

\section{NECESSARY FORMATION OF POSITIVE IMAGE OF THE ENTERPRISE AS AN INTERNAL STRATEGIC MANAGEMENT TOOL}

\author{
Chupyr O.M., Doctor of Economic Sciences, Associate Professor, Professor \\ (KNUCA)
}

The modern dynamic pace of life and business development dictates its rules of survival, which is characterized by changes in the structure and life of society. The saturation of the market of goods and services, the creation of a competitive environment leads to the need to use marketing technologies, one of the elements of which is the formation and strengthening of corporate image. Under present conditions, a favorable image of an enterprise is an important and necessary factor for effective management. Functioning in a competitive environment, each business must be careful about creating a positive image that in the future will ensure the attention and commitment of customers, partners, attractiveness for investors and, ultimately, successful activities.

In economically developed countries, the interest in managing image politics has grown significantly over the past decade. In today's economic environment, the use of a positive image of the company as an instrument of internal strategic management becomes more and more relevant in connection with the fierce market competition between enterprises. Insufficient attention to the formation and creation of a positive image entails negative consequences. The article considers the meaning and essence of the use of a positive image for the enterprise, the rationale of its creation. The emphasis is on the generalization of the factors that influence the creation of a positive image of the enterprise, on the fulfillment of certain tasks concerning its achievement. The model of formation of a positive image of the enterprise in the conditions of the current economic situation is developed, which will enable

Вісник економіки транспорту і промисловості № 65, 2019 
not only to improve the efficiency of the company as a whole, but also to strengthen its competitive position, resulting in an economic and social effect.

Key words: image, positive image, model, formation of a positive image, strategic management, image equivalents.

\section{Постановка}

Посилення кризових явищ в економіці породжує необхідність відстеження кризових тенденцій i розробку своєчасних заходів, змушує вчених i практиків включатися в дослідження та рішення проблем, пов'язаних із діагностикою стану факторів зовнішнього та внутрішнього середовища підприємства, розробкою цілей, стратегій підприємства та способів їх реалізації. В цьому зв'язку все більшу увагу звертають на себе методи стратегічного управління, що добре зарекомендували себе як дієвий інструмент в умовах нестабільного оточення. Серед багатьох одним із стратегічних факторів розвитку підприємства стає його позитивний імідж, який створює привабливість підприємства, спричиняє вплив на відносини 3 партнерами та покупцями, забезпечує конкурентоспроможність підприємства.

$$
\text { У сучасних }
$$

умовах

господарювання у зв'язку з наповненням ринку виробництвом товарів і послуг на перший план виходять іміджеві еквіваленти (успішна реклама, репутація підприємства й інші), ніж технологічні характеристики. В процесі розвитку виробництва величезне значення набуває сфера організації й управління, де імідж відіграє роль активації й інтенсифікації ресурсів, зокрема, i людських. Позитивний імідж виступає не тільки основним критерієм успішності особистості або ефективного розвитку підприємства, але й $є$ ідентифікатором вибору товарів і послуг в умовах конкуренції. Саме конкуренція змушує підприємства боротися за право існування на ринку. Підприємство, зайнявши певну позицію, всіма силами намагається іiі утримати, завоювати міцну репутацію та престиж. Сприятливе уявлення щодо підприємства сприяє кращому попиту на його товар або послугу. У зв'язку 3 підвищеною значущістю іміджу підприємств необхідно ретельно підходити до питання практичної сторони формування іміджу. Таким чином, імідж виступає в економіці інструментом стратегічного управління, функціональною стратегією.

\section{Аналіз останніх досліджень i} публікацій. Питання, пов'язані 3 теоретичним обгрунтуванням іміджу, а також його формуванням знайшли своє відображення в роботах вітчизняних i зарубіжних авторів, таких як: Гера О.Г. [6], Гофман Е. [7], Гринько Т. [1], Дрончак I.B. [4], Костюк Г.В. [2], Котлер Ф. [3], Лозовський О.М. [4], Пасько M.I. [5], Семенчук Т.Б. [6], Сторожук В.В. [2], Тімар I. [1] та інших.

Виділення невирішених частин загальної проблеми. Незважаючи на достатню кількість наукових праць i значні досягнення в теорії та практиці іміджеології, деякі питання потребують більш значної уваги.

Метою статті $\epsilon$ обгрунтування необхідності формування позитивного іміджу підприємства як дієвого інструменту внутрішнього стратегічного управління в сучасних умовах господарювання 3 визначенням його складових елементів.

Виклад основного матеріалу дослідження. В сучасних ринкових умовах одним 3 основних чинників економічного благополуччя підприємства $\epsilon$ ринок, а якщо казати більш точно покупець продукції та послуг. Мінливість i невизначеність зовнішніх умов, в яких перебуває та діє підприємство, ні в кого на даний момент не викликає сумнівів. Фактори 
зовнішнього середовища, що суттєво впливають на діяльність підприємства, це стрибки валютних курсів, зміни політико-правового та соціального становища й інші. Для підприємства дуже важливо не тільки враховувати зовнішні фактори, але й піклуватися щодо конкурентоспроможності підвищення шляхом формування позитивного іміджу на ринку. Позитивний імідж несе за собою переваги, що проявляються в привертанні уваги споживачів і партнерів, полегшенні підприємству доступу до ресурсів, увазі засобів масової інформації, захищеності в кризових і скрутних становищах.

Процес формування іміджу розглядається переважно в категоріальному полі психологї та соціології; проникає феномен іміджу і в педагогіку, філософію. Для економічної науки більш прийнятним є поняття «корпоративний імідж підприємства», у зв'язку 3 чим розглядаються науковометодичні основи його формування, процес управління іміджом, внутрішні особливості суб'єкта (або об'єкта) іміджу. Імідж в економіці визначається ще як «репутація». Поняття «імідж» має багато різних визначень (табл. 1).

Таблиия 1

\section{Сутність поняття «імідж»}

\begin{tabular}{|c|c|}
\hline Автори & Поняття \\
\hline $\begin{array}{l}\text { 1. Костюк Г.В., } \\
\text { Сторожук В.В. }\end{array}$ & $\begin{array}{l}\text { Імідж підприємства - це сформоване представлення цільовій } \\
\text { аудиторії інформації щодо діяльності та успіхів підприємства, що } \\
\text { постійно та динамічно впливає на взаємини підприємства з його } \\
\text { потенційними та фактичними покупцями, на його } \\
\text { конкурентоспроможність, фінансові результати та контакти з } \\
\text { іншими державними або приватними підприємствами, установами й } \\
\text { організаціями. }\end{array}$ \\
\hline 2. Пасько М.I. & $\begin{array}{l}\text { Імідж підприємства - це багатокомпонентне явище, образ-уявлення } \\
\text { та образ-подання щодо організації, кадри, якість продукції (послуг), } \\
\text { репутацію керівника тощо, який сформувався власне засобами } \\
\text { масової інформації, соціальною групою або підприємством і } \\
\text { наділяє його (підприємство) додатковими цінностями, що мають } \\
\text { соціальну значущість для реципієнтів образу фірми, і спрямований } \\
\text { здійснити емоційно-психологічну дію на цільову аудиторію, із } \\
\text { метою популяризації, реклами та інших завдань під впливом } \\
\text { комплексу факторів. }\end{array}$ \\
\hline $\begin{array}{l}\text { 3. Семенчук Т.Б., } \\
\text { Гера О.Г. }\end{array}$ & $\begin{array}{l}\text { Імідж - це образ, репутація, якісні характеристики лідера, фірми, } \\
\text { керівника та характер ставлення до них громадськості. }\end{array}$ \\
\hline 4. Гринько Т., Тімар I. & $\begin{array}{l}\text { Імідж підприємств сфери послуг - це відносно стійке, емоційно } \\
\text { забарвлене уявлення образу підприємства, сформоване на основі } \\
\text { особистого досвіду й отриманої інформації щодо його реальні, } \\
\text { декларовані та очікувані якості, характеристики та показники, що } \\
\text { мають економічну, соціальну й іншу значимість для суб'єктів } \\
\text { взаємодії. }\end{array}$ \\
\hline $\begin{array}{l}\text { 5. Лозовський О.М., } \\
\text { Дрончак I.В. }\end{array}$ & $\begin{array}{l}\text { Визначення іміджу має охоплювати: спрямованість на певну } \\
\text { соціальну групу; відображення потреб і запитів аудиторії на певний } \\
\text { час; символічну природу (існування стереотипів у психіці); } \\
\text { гнучкість і ситуативність, залежність від моменту, з одного боку, та } \\
\text { постійність, статичність - з другого; поєднання зовнішніх і } \\
\text { внутрішніх складових при формуванні; соціально-психологічне } \\
\text { походження. Імідж - одна з найважливіших складових } \\
\text { конкурентоспроможності підприємства, базова передумова його } \\
\text { успішної діяльності. }\end{array}$ \\
\hline 6. Котлер $\Phi$. & Імідж - це сприйняття компанії чи її товарів суспільством. \\
\hline 7. Гофман Е. & Імідж -мистецтво управляти враженням. \\
\hline
\end{tabular}


На думку автора, імідж управління підприємства в умовах підприємства - це чинник довіри до жорсткої конкуренції для забезпечення підприємства, його товарів чи послуг, його інтересів. Формуючи позитивний який цілеспрямовано створюється та імідж підприємства, необхідно входить у свідомість або підсвідомість враховувати вплив безлічі факторів цільової аудиторії з метою формування (рис. 1). позитивного образу, а також є дієвим інструментом внутрішнього стратегічного

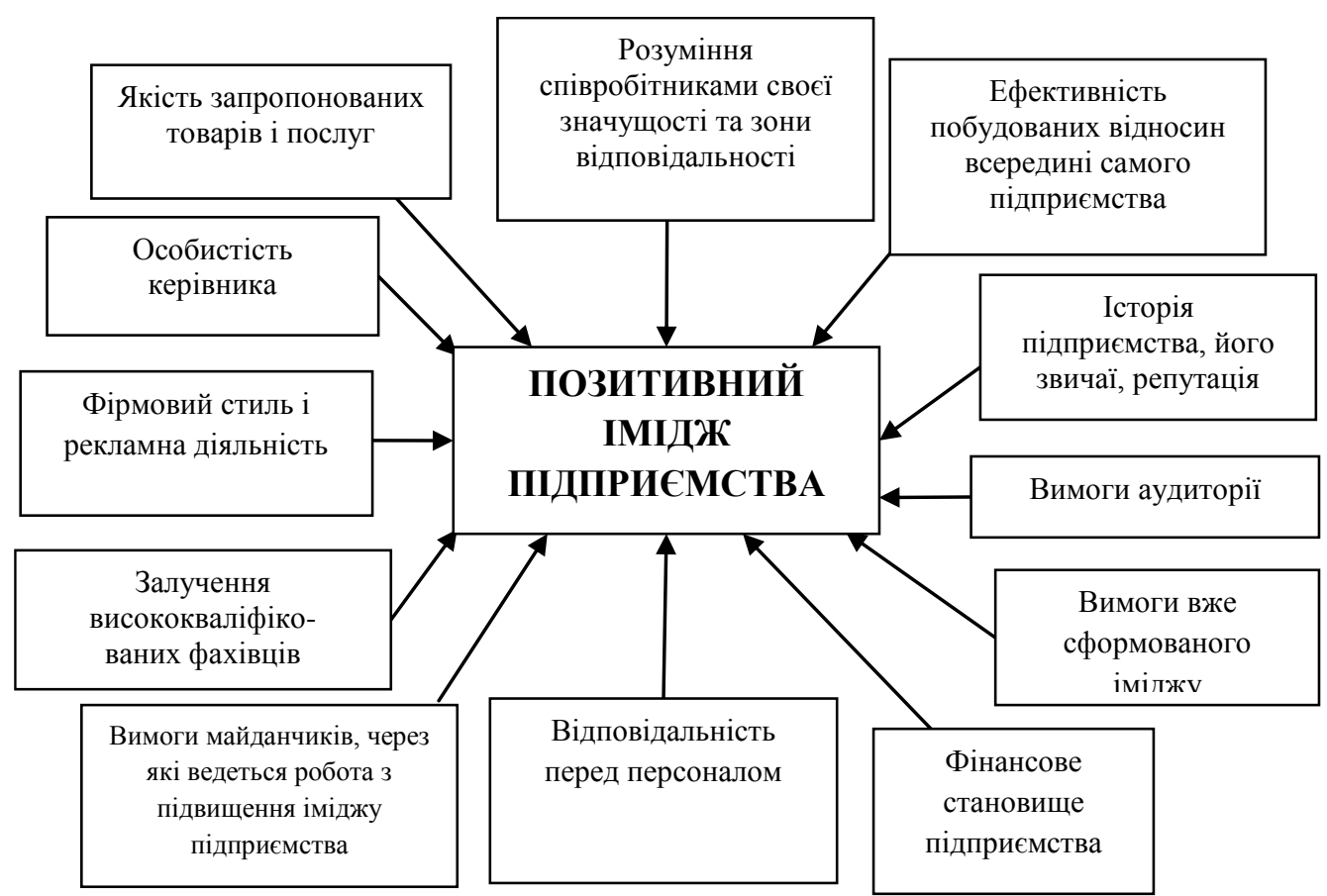

Рис. 1. Фактори, щчо впливають на формування позитивного іміджу підприємства

Беручи до уваги перелічені позитивного іміджу підприємства. Однак, фактори, досить складно виробити певний можна виділити основні моменти, на яких шлях, спрямований на створення необхідно акцентувати увагу (рис. 2, 3).

\begin{tabular}{|c|c|c|c|}
\hline $\begin{array}{c}\text { Підпри- } \\
\text { ємство, що } \\
\text { потребує } \\
\text { створення } \\
\text { позитивного } \\
\text { іміджу }\end{array}$ & $\begin{array}{l}\text { 1. Закладення } \\
\text { основи з } \\
\text { урахуванням } \\
\text { факторів, які } \\
\text { впливають на } \\
\text { створення } \\
\text { позитивного } \\
\text { іміджу } \\
\text { підприємства }\end{array}$ & $\begin{array}{l}\text { 2. Внутрішній імідж: } \\
\text { фінансове } \\
\text { планування; } \\
\text { кадрова політика } \\
\text { підприємства }\end{array}$ & $\begin{array}{l}\text { 3. Зовнішній } \\
\text { імідж: якість } \\
\text { продукції,послуг; } \\
\text { реклама; } \\
\text { громадська } \\
\text { діяльність; } \\
\text { ставлення } \\
\text { персоналу щодо } \\
\text { роботи та його } \\
\text { зовнішній вигляд }\end{array}$ \\
\hline
\end{tabular}

Рис. 2. Етапи формування позитивного іміджу підприємства 


\begin{tabular}{|c|c|c|c|}
\hline $\begin{array}{c}\text { Підпри- } \\
\text { ємство, що } \\
\text { перебуває } \\
\text { на стадії } \\
\text { формуван- } \\
\text { ня }\end{array}$ & $\begin{array}{l}1 . \text { Закладен- } \\
\text { ня основи } 3 \\
\text { урахуван- } \\
\text { ням } \\
\text { факторів, } \\
\text { які } \\
\text { впливають } \\
\text { на } \\
\text { створення } \\
\text { позитивно- } \\
\text { го іміджу } \\
\text { підприємс- }\end{array}$ & $\begin{array}{l}\text { 2. Внутрішній імідж: - } \\
\text { визначення цілей } \\
\text { функціонування } \\
\text { підприємства та } \\
\text { складання термінових } \\
\text { планів; } \\
\text { - створення товарного } \\
\text { знаку, логотипу } \\
\text { підприємства; } \\
\text { - підбір персоналу; } \\
\text { розробку загального } \\
\text { стилю компанії; } \\
\text { - складання прогнозів } \\
\text { розвитку, спираючись } \\
\text { на маркетингові } \\
\text { дослідження; } \\
\text { - створення бази для } \\
\text { потенційних клієнтів } \\
\text { після заняття_певної } \\
\text { ніші: } \\
\text { - створення } \\
\text { корпоративного духу; } \\
\text { - зміцнення традицій; } \\
\text { - прагнення щодо } \\
\text { максимального } \\
\text { виконання обов'язків } \\
\text { персоналу }\end{array}$ & $\begin{array}{l}\text { 3. Зовнішній імідж. На } \\
\text { початковому етапі } \\
\text { діяльності: } \\
\text { - мінімальні витрати на } \\
\text { рекламу; } \\
\text { - формування } \\
\text { враження у партнерів і } \\
\text { клієнтів щодо } \\
\text { діяльності } \\
\text { підприємства. } \\
\text { Після заняття певної } \\
\text { ніші: } \\
\text { - підтримання } \\
\text { стабільності діяльності } \\
\text { підприємства; } \\
\text { - налагодження } \\
\text { постійного зв'язку з } \\
\text { існуючими клієнтами; } \\
\text { - збільшення витрат на } \\
\text { рекламу; реклама в } \\
\text { різних ЗМІ }\end{array}$ \\
\hline
\end{tabular}

Рис. 3. Етапи створення позитивного іміджу підприємства, що перебуває на стадії формування

Процес формування іміджу $\epsilon$ достатньо складним процесом, який потребує немало зусиль, концентрації уваги та зважених рішень.

На рис. 4 наведено узагальнену та сформовану модель створення позитивного іміджу підприємства

Щоб досягти позитивного іміджу, підприємство повинно виконати ряд основних завдань, серед яких можна виділити наступні: компетентність у своїй галузі; ефективну роботу 3 клієнтами; підтримку іміджу успішної компанії, що викликала би в клієнтів довіру. Кожне підприємство повинне створювати свою іміджеву політику, як зовнішню, так і внутрішню, покликану забезпечити максимальний прибуток на певному етапі роботи.
Висновок. Таким чином, у сучасних умовах господарювання необхідно, перш за все, пам'ятати, що саме імідж може суттєво вплинути на конкурентну стійкість суб'єкта господарювання та зміцнити іiі.

Формувати позитивний імідж у склавшихся на сьогодні умовах досить складно з-за загостреної політичної й економічної ситуацій у державі.

Запропонована модель формування позитивного іміджу підприємства ще раз підкреслює комплексність і взаємозв'язаність усіх складових його елементів, які є відображенням цілісного уявлення та сприйняття, а також дієвим інструментом внутрішнього стратегічного управління підприємства. 


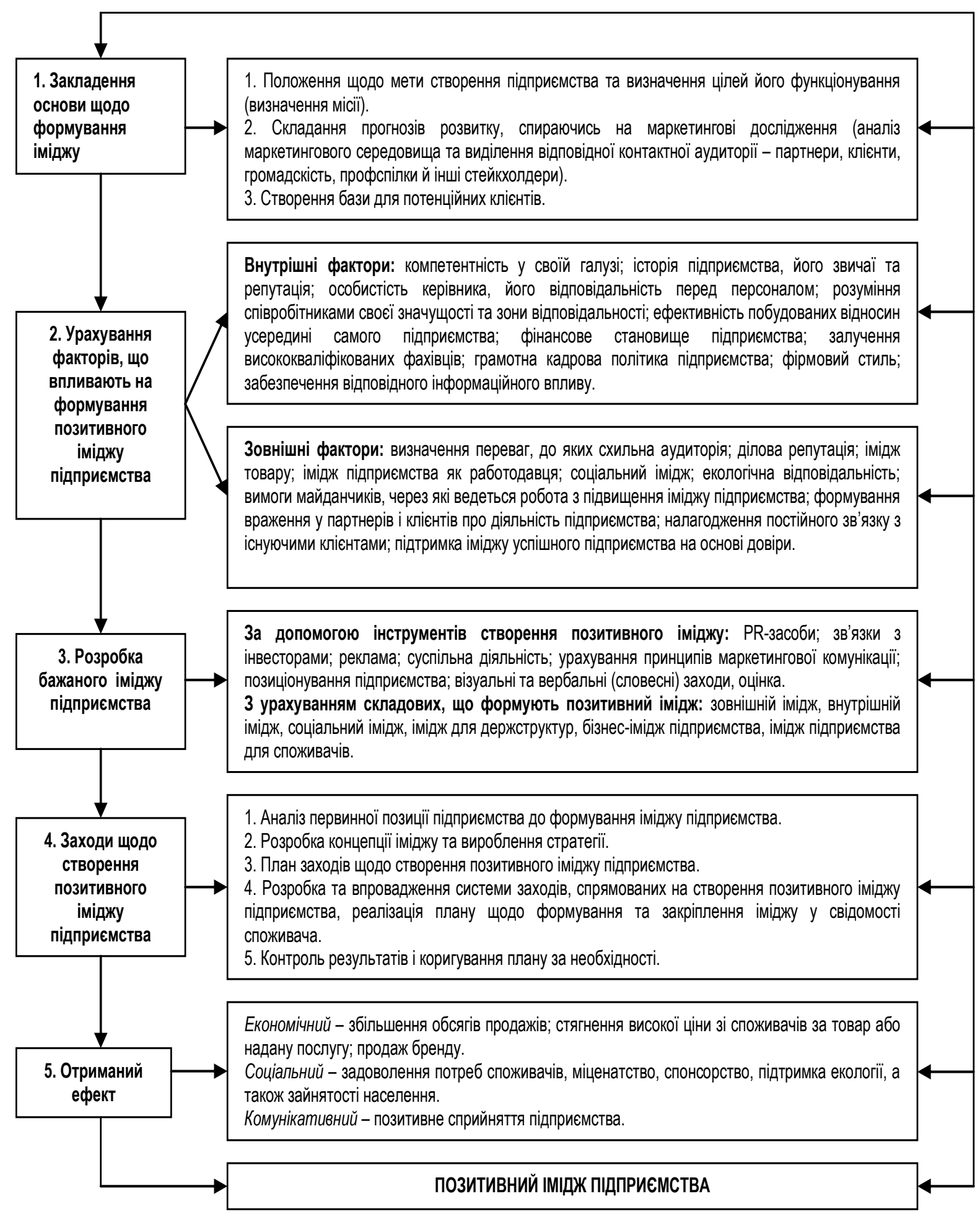

Рис. 4. Модель формування позитивного іміджу підприємства

ПЕРЕЛІК ВИКОРИСТАНИХ ДЖЕРЕЛ http://ven.chdtu.edu.ua/article/viewFile/84534/ 80074. - Назва з екрану.

1. Гринько T., Тімар I. Імідж підприємств сфери послуг: сутність поняття та особливості формування [Електорнний ресурс] / T. Гринько, I. Тімар - Режим доступу:

2. Костюк Г. В. Сторожук В.В. Формування позитивного іміджу підприємства / Г. В. Костюк, В. В. Сторожук // Вісник КНУТД. - 2014. - № 1. - C. 176-181. 
3. Котлер Ф., Лі Н. Корпоративна соціальна відповідальність. Як зробити якомога більше добра для вашої компанії та суспільства / Ф. Котлер, Н. Лі // Ж.: Изд-во А. Капусты, 2005. - 302 с.

4. Лозовський О.М., Дрончак I.В. [Електорнний ресурс] / О.М. Лозовський, I.B. Дрончак - Режим доступу: http://molodyvcheny.in.ua/files/journal/2016/1/ 23.pdf - Назва з екрану.

5. Пасько М. I. Характеристика та особливості іміджу підприємства / М. І. Пасько // Економіка розвитку. - 2018. - № 1 (85). - C. 58-65.

6. Семенчук Т.Б., Гера О.Г. Сучасна модель формування іміджу організації / Т.Б. Семенчук, О.Г. Гера // Науковий вісник Херсонського державного університету. 2014. - №7 (3). - С. 178-181.

7. Сизоненко В.О. Сучасне підприємництво: довідник

В.О. Сизоненко // К.: Знання-Прес, 2007. $440 \mathrm{c}$.

\section{REFERENCES}

1. Ghrynjko T., Timar I. Imidzh pidpryjemstv sfery poslugh: sutnistj ponjattja ta osoblyvosti formuvannja [Imidzh pidpriemstv spherya poslug: sutnist ponyattya that particular shape]. Available at:
http://ven.chdtu.edu.ua/article/viewFile/84534/ 80074.

2. Kostjuk Gh. V. Storozhuk V.V. (2014) Formuvannja pozytyvnogho imidzhu pidpryjemstva [Formation of a positive image of the enterprise]. KNUTD Bulletin. No. 1, pp. 176-181.

3. Kotler F., Li N. (205) Korporatyvna socialjna vidpovidaljnistj. Jak zrobyty jakomogha biljshe dobra dlja vashoji kompaniji ta suspiljstva [Corporate Social Responsibility. How to do as much good as possible for your company and society]. Zh.: Izdvo A.

4. Lozovsjkyj O.M., Dronchak I.V. Available at: http://molodyvcheny.in. ua/files/journal/2016/1/23.pdf

5. Pasjko M. I. (2018) Kharakterystyka ta osoblyvosti imidzhu pidpryjemstva [Characteristics and features of the company's image]. Development Economics. No 1(85), pp. 58-65.

6. Semenchuk T.B., Ghera O.Gh. (2014) Suchasna modelj formuvannja imidzhu orghanizaciji [Modern model of organization's image formation]. Scientific Herald of Kherson State University. No 7 (3), pp. 178-181.

7. Syzonenko V.O. (2007) Suchasne pidpryjemnyctvo: dovidnyk. [Contemporary entrepreneurship: a guide]. $\mathrm{K} .:$ KnowledgePress (in Ukrainian)

\section{АДАПТИВНЕ УПРАВЛІННЯ ІНВЕСТИЦЙНОЮ ПОЛІТИКОЮ ПІДПРИЕМСТВА}

\section{Яремко А.Д., аспірант (УІПА)}

Розроблена модель процесу формування та реалізації інвестииійної політики підприємства в межах системи адаптивного управління дозволяе сформувати на підприємстві власні регламенти ї̈ реалізачії. Планування, реалізаџія $і$ контроль всієї сукупності інвестиційних рішень підприємства в межах системи адаптивного управління дозволяє на постійній основі відстежувати $і$ регулювати ефективність використання всього капіталу підприємства і підвищити його антикризовий потенціал. 